\title{
ANALISIS KEMAMPUAN BERPIKIR KRITIS SISWA KELAS X SMA DALAM MENYELESAIKAN MASALAH IDENTITAS TRIGONOMETRI DITINJAU DARI GENDER
}

\author{
Syafruddin Kaliky, Fahruh Juhaevah \\ Jurusan Pendidikan Matematika FITK IAIN Ambon \\ kalikysyafruddin@iainambon.ac.id
}

\begin{abstract}
Abstrak
Penelitian ini bertujuan untuk menganalisis kemampuan berpikir kritis dalam menyelesaikan masalah identitas trigonometri ditinjau dari gender di SMA. Dalam pengambilan subjek dilakukan dengan cara think a loud. Siswa yang cenderung memenuhi kriteria berpikir kritis selanjutnya dikelompokkan berdasarkan gender. Berdasarkan data jenuh yang diperoleh berdasarkan masing-masing gender, selanjutnya di ambil masing-masing satu orang untuk dianalisis kemampuan berpikir kritis. Berdasarkan hasil analisis kemampuan berpikir kritis ditinjau dari gender dalam menyelesaikan masalah identitas trigonometri diperoleh bahwa siswa yang berjenis kelamin laki-laki dan siswa yang berjenis kelamin perempuan cenderung memenuhi 5 indikator berpikir kritis yaitu (1) mampu merumuskan pokok permasalahan; (2) mampu mengungkapkan fakta yang dibutuhkan dalam menyelesaikan suatu masalah; (3) mampu memilih argumen yang logis, relevan dan akurat; (4) mampu mendeteksi bias berbeda pada sudut pandang berbeda dan (5) Mampu menentukan akibat dari suatu pernyataan yang di ambil sebagai suatu keputusan. Dalam proses penyelesaian berdasarkan tahapannya tampak bahwa siswa perempuan cenderung teliti dan sistematis dibandingkan siswa laki-laki.
\end{abstract}

Kata kunci: Kemampuan berpikir kritis, gender.

\begin{abstract}
This study aimed to analyze critical thinking ability when solved trigonometry identity problem based on gender difference in senior high school. Subject were selected by think a loud. Most of student can do critical thinking criteria and then make a group difference based on gender. Based on saturated data that have obtained for each gender, and then take one of them to analyze critical thinking ability. Based on result shows that male student and female student mostly can complete five indicators of critical thinking such as 1) can formulate the core problem; 2) can express fact that requirement to solve the problem; 3) can choose logically argument, relevant, and accurate; 4) can detect different refraction when get different solution; and 5) can determint cause of the statement that it have took as a decision. When solved the problem based on the its phase, showed that female student are more careful and more sistematic than male student.
\end{abstract}

Keywords: Critical thinking ability, gender.

Sitasi: Kaliky, S., Juhaevah, F. 2018. Analisis Kemampuan Berpikir Kritis Siswa Kelas $\mathrm{X}$ SMA dalam Menyelesaikan Masalah Identitas Trigonometri Ditinjau dari Gender. Matematika dan Pembelajaran, 6(2), 111-126. 


\section{PENDAHULUAN}

Isu mutakhir dalam pembelajaran matematika saat ini adalah mengembangkan High-Order Thinking Skill (HOTS) dan menjadikannya sebagai tujuan utama dalam pembelajaran matematika. Pernyataan ini antara lain didukung oleh The National Education Association Research Division (Ghokhale, 1997: 1): "Student Acquisition of high-order thinking skills is now a nation goal". Sejalan dengan pendapat tersebut, salah satu harapan yang ingin dicapai dalam pembelajaran matematika di sekolah adalah dimilikinya kemampuan berpikir kritis. Kemampuan ini sangat diperlukan siswa terkait dengan kebutuhan siswa untuk memecahkan masalah yang dihadapinya dalam kehidupan sehari-hari.

Hal ini didukung berdasarkan tim Survey IMSTEP-JICA (1999) di kota Bandung menemukan sejumlah kegiatan yang dianggap sulit oleh siswa untuk mempelajarinya dan oleh guru untuk mengajarkannya antara lain, pembuktian pemecahan masalah yang memerlukan penalaran matematis, menemukan, generalisasi atau konjektur, dan menemukan hubungan antara data-data atau fakta yang diberikan. Kegiatan-kegiatan yang dianggap sulit tersebut, kalau diperhatikan merupakan kegiatan yang menuntut kemampuan berpikir kritis. Dengan demikian, disimpulkan bahwa hasil survey tersebut menemukan bahwa siswa mengalami kesulitan jika dihadapkan kepada persoalan yang memerlukan kemampuan berpikir kritis.

Sebagai contoh yang diperoleh saat observasi di sekolah SMA 3 SALAHUTU, pada saat proses pembelajaran berlangsung terkait materi trigonometri, guru mengatakan bahwa $\pi=180^{\circ}$. Namun pada waktu yang bersamaan, ada siswa yang menyikapi situasi tersebut dengan mengatakan nilai $\pi=22 / 7$. Secara tidak langsung, hal ini menunjukkan bahwa siswa tersebut telah berpikir kritis. Oleh karena itu, kemampuan berpikir kritis terutama yang menyangkut doing math (aktivitas matematika) perlu mendapat perhatian khusus dalam proses pembelajaran matematika.

Berpikir kritis merupakan suatu proses yang bermuara pada pembuatan kesimpulan atau keputusan yang logis tentang apa yang harus diyakini dan tindakan apa yang harus dilakukan. Berpikir kritis bukan untuk mencari jawaban semata, tetapi yang lebih utama adalah menanyakan kebenaran jawaban, fakta, atau informasi yang ada. Dengan demikian bisa ditemukan alternatif atau solusi terbaiknya. Selanjutnya menurut Chaffee (Suriadi, 2006), berpikir kritis adalah berpikir untuk menyelidiki secara sistematis proses berpikir 
itu sendiri. Artinya bahwa tidak hanya memikirkan dengan sengaja, tetapi juga meneliti bagaimana kita dan orang lain menggunakan bukti dan logika. Sejalan dengan pendapat tersebut, Norris (Fowler, 1996) mendefinisikan berpikir kritis sebagai pengambilan keputusan secara rasional apa yang diyakini dan dikerjakan. Sedangkan menurut Ennis (2000), berpikir kritis adalah berpikir rasional dan reflektif yang difokuskan pada apa yang diyakini dan dikerjakan. Dengan demikian disimpulkan bahwa berpikir kritis adalah suatu ketrampilan yang harus dimiliki agar bisa berkomunikasi serta pengambilan keputusan.

Begitu pentingnya berpikir kritis sehingga menjadi bahan perhatian bagi para pendidik maupun peneliti. Salah satu ahli yang mengemukakan terkait pentingnya berpikir kritis diantaranya menurut Facione (2006) yaitu sebagai pengaturan diri dalam memutuskan (judging) sesuatu yang menghasilkan interpretasi, analisis, evaluasi dan inferensi, maupun pemaparan menggunakan suatu bukti, konsep, metodologi, kriteria, atau pertimbangan kontekstual yang menjadi dasar dibuatnya keputusan. Selain itu, berpikir kritis juga penting sebagai alat inquiry. Terlepas dari pentingnya berpikir kritis, berpikir kritis sangat bermanfaat dalam membuat seseorang menjadi lebih mandiri, percaya diri dan mampu memecahkan persoalan dengan lebih bijak.

Indikator kemampuan berpikir kritis dapat diturunkan dari aktivitas kritis siswa sebagai berikut : (1) Mencari pernyataan yang jelas dari setiap pertanyaan; (2) Mencari alasan; (3) Berusaha mengetahui informasi dengan baik; (4) Memakai sumber yang memiliki kredibilitas dan menyebutkannya; (5) Memperhatikan situasi dan kondisi secara keseluruhan; (6) Berusaha tetap relevan dengan ide utama; (7) Mengingat kepentingan yang asli dan mendasar; (8) Mencari alternatif; (9) Bersikap dan berpikir terbuka; (10) Mengambil posisi ketika ada bukti yang cukup untuk melakukan sesuatu; (11) Mencari penjelasan sebanyak mungkin apabila memungkinkan; (12) Bersikap secara sistematis dan teratur dengan bagian-bagian dari keseluruhan masalah (Ennis dalam Hassoubah, 2004).

Indikator kemampuan berpikir kritis yang diturunkan dari aktivitas kritis no. 1 adalah mampu merumuskan pokok-pokok permasalahan. Indikator yang diturunkan dari aktivitas kritis no. 3, 4, dan 7 adalah mampu mengungkap fakta yang dibutuhkan dalam menyelesaikan suatu masalah. Indikator yang diturunkan dari aktivitas kritis no. 2, 6, dan 12 adalah mampu memilih argumen logis, relevan dan akurat. Indikator yang diturunkan dari aktivitas kritis no. 8, 10, dan 11 adalah mampu mendeteksi bias berdasarkan pada 
sudut pandang yang berbeda. Indikator yang diturunkan dari aktivitas kritis no. 5 dan 9 adalah mampu menentukan akibat dari suatu pernyataan yang diambil sebagai suatu keputusan.

Dengan demikian, indikator kemampuan berpikir kritis yang digunakan dalam penelitian ini adalah (1) Mampu merumuskan pokok-pokok permasalahan; (2) Mampu mengungkapkan fakta-fakta yang dibutuhkan dalam menyelesaikan suatu masalah; (3) Mampu memilih argumen yang logis, relevan dan akurat; (4) Mampu mendeteksi bias berbeda pada sudut pandang yang berbeda; (5) Mampu menentukan akibat dari suatu pernyataan yang di ambil sebagai suatu keputusan.

Oleh karena itu, berpikir kritis sangat dibutuhkan oleh setiap orang dalam belajar karena otak manusia secara konstan berusaha memahami pengalaman. Pencariannya yang terus menerus akan makna, otak dengan tangkas menghubungkan ide abstraks dengan konteksnya di dunia nyata. Dalam pembelajaran matematika, pemberian soal-soal tidak rutin atau tugas-tugas yang berhubungan dengan dunia nyata dan berkaitan dengan kehidupan sehari-hari, akan membantu siswa melihat makna dari yang dipelajarinya karena ia dapat menghubungkan informasi yang diterima dengan pengetahuan dan pengalaman yang dimilikinya. Untuk siswa-siswa, soal yang diberikan harus sesuai dengan tingkat kemampuan kognitif anak.

Tidak terlepas dari matematika ternyata tingkat kemampuan berpikir kritis juga dipengaruhi oleh Gender (Jenis kelamin) Menurut Aminah Ekawati dan Shinta Wulandari (2011), dalam penelitiannya secara biologis laki-laki dan perempuan berbeda. Perbedaan itu terlihat jelas pada alat reproduksi. Perbedaan biologis laki-laki dan perempuan disebabkan oleh adanya hormon yang berbeda antara laki-laki dengan perempuan. Dengan adanya perbedaan ini berakibat pada perlakuan yang berbeda terhadap laki-laki dan perempuan. Selain faktor biologis, faktor lain yang mempengaruhi prestasi belajar siswa adalah faktor psikologis. Secara psikologis laki-laki dan perempuan berbeda. Faktor psikologis terkait dengan intelegensi, perhatian, minat, bakat, disiplin, kematangan, dan kesiapan.

Selain itu, penelitian juga dilakukan oleh Hyde dan Linn (1988) (Rita, 172), dalam tes SAT menunjukkan bahwa laki-laki dan perempuan memiliki nilai yang kira-kira sama pada bagian verbal, tetapi laki-laki memiliki nilai yang lebih tinggi secara bermakna pada bagian matematika. Satu bidang kemampuan kognitif yang terus menunjukkan perbedaan jenis kelamin yanng konsisten adalah hubungan visual-spasial. Dalam tes tersebut menunjukkan bahwa laki-laki memiliki nilai yang lebih tinggi, terutama jika tugas atau 
tes tersebut ditentukan waktunya dan mengharuskan rotasi mental terhadap objek. Penelitian ini selanjutnya akan menganalisis kemampuan berpikir kritis siswa di SMA dalam menyelesaikan masalah identitas trigonometri ditinjau dari gender.

\section{METODE}

Berdasarkan tujuan penelitian ini bahwa untuk menganalisis kemampuan berpikir kritis siswa di SMA dalam menyelesaikan masalah identitas trigonometri ditinjau dari gender, maka peneliti melakukan wawancara mendalam terhadap beberapa siswa yang sebelumnya telah diberikan tes dengan think a loud. Siswa-siswa tersebut kemudian dikelompokkan atas kelompok laki-laki dan kelompok perempuan. Berdasarkan data kejenuhan dari tiap kelompok pada gender, selanjutnya dilakukan analisis kemampuan berpikir kritis terhadap subjek AT yang mewakili perempuan dan subjek SM yang mewakili laki-laki. Jenis penelitian ini adalah penelitian deksriptif dengan pendekatan kualitatif.

Sehubungan dengan penelitian ini, peneliti berusaha menggali informasi melalui pengamatan, tes dengan think a loud serta proses wawancara dengan siswa-siswa yang dijadikan sebagai calon subjek untuk mendapatkan informasi mengenai objek yang akan digali yaitu kemampuan berpikir kritis. Dalam proses analisis data kualitatif dengan mengacu pada tiga langkah menurut Miles dan Huberman (Sugiyono, 2006) diantaranya reduksi data, penyajian data dan penarikan kesimpulan.

\section{HASIL DAN PEMBAHASAN}

Data yang dikumpulkan dalam penelitian ini, terdiri atas data tentang kemampuan berpikir kritis yang diperoleh dari tes dengan think a loud dan wawancara. Berikut hasil penelitian dapat diuraikan sebagai berikut.

\section{Paparan data subjek SM berjenis kelamin laki-laki dalam menyelesaikan masalah identitas trigonometri}

\section{a. Mampu merumuskan pokok permasalahan}

Salah satu indikator dari berpikir kritis adalah mampu merumuskan pokok permasalahan dari masalah yang diberikan. Artinya bahwa siswa mencari pernyataan yang jelas dari setiap pertanyaan yang ada. Setelah subjek mengerjakan soal yang diberikan berupa think a loud tampak bahwa subjek awalnya berpikir terkait cara dalam menyelesaikannya dengan menuliskan kembali masalah yang ada pada lembar jawabannya. 
Hal ini dapat ditunjukan pada penggalan hasil pekerjaan subjek sebagai berikut.

$$
\text { b. } 3 \cos ^{2} a-2=1-3 \sin ^{2} a
$$

Berdasarkan hasil wawancara, subjek mengungkapkan bahwa "karena soal yang disajikan telah berbentuk kalimat matematika dalam bentuk identitas trigonometri sehingga saya hanya menuliskan ulang kembali. Hal ini dikarenakan soal tersebut adalah sebuah masalah yang nanti akan disederhanakan untuk mendapatkan solusi”. Peneliti selanjutnya mendalami bahwa bagaimana cara dibuktikan masalah tersebut, subjek kemudian mengemukakan bahwa "hal tersebut dibuktikan dengan menyamakan hasil pada ruas kiri sama dengan pada ruas kanan". Dari hasil tes dan wawancara menunjukkan bahwa subjek laki-laki lebih mampu dan tanggap dalam mengenali masalah yang ada. Didukung dengan pendapat Kant bahwa perbedaan antara lakilaki dan perempuan yang terletak pada arah pengenalan masalahnya.

Hal ini menunjukkan bahwa subjek memahami masalah yang ada untuk menuju proses penyelesaian. Dengan demikian subjek SM dapat dikatakan cenderung memenuhi indikator pertama yaitu mampu merumuskan pokok permasalahan dari masalah yang diberikan.

\section{b. Mampu mengungkapkan fakta yang dibutuhkan dalam menyelesaikan suatu masalah}

Pada indikator ini menunjukkan bahwa dalam proses penyelesaian masalah yang diberikan subjek dituntut berusaha mengetahui informasi dengan baik; Memakai sumber yang memiliki kredibilitas dan menyebutkannya, serta mengingat kepentingan yang asli dan mendasar.

Berdasarkan hasil tes yang diperoleh subjek terlihat bahwa subjek cenderung dalam proses penyelesaian dengan menuliskan rumus aturan identitas trigonometri. Hal ini ditunjukkan pada penggalan hasil pekerjaan berikut.

$$
\text { Selup } \sin ^{2} a+\cos ^{2} a=1 \text { maka }
$$

Berdasarkan jawaban subjek menunjukkan bahwa subjek membuktikan masalah yang diberikan dengan bantuan aturan identitas trigonometri. Peneliti 
selanjutnya menggali lebih mendalam terkait penggunaan aturan identitas tersebut. Subjek kemudian mengemukakan bahwa "untuk membuktikan identitas trigonometri lebih mudahnya beranjak dari rumus umum kemudian tinggal menyamakan koefisien dan langsung membuktikan ruas kiri dan kanan”. Sejalan dengan pendapat Myers (2006) bahwasanya tidak ada perbedaan yang nyata kemampuan berpikir kritis antara siswa laki-laki dan perempuan. Hal ini menunjukkan dalam proses pengungkapan fakta dari masalah yang ada untuk proses penyelesaian antara subjek perempuan dan laki-laki cenderung sama.

Dengan demikian, subjek dalam menyelesaikan soal identitas trigonometri cenderung memenuhi indikator kedua dari proses berpikir kritis.

\section{c. Mampu memilih argumen yang logis, relevan dan akurat}

Pada indikator ini menunjukkan bahwa dalam proses penyelesain soal, subjek harus mencari alasan yang cocok dengan masalah yang diberikan, berusaha tetap relevan dengan ide utama, serta bersikap secara sistematis dan teratur dengan bagian-bagian dari keseluruhan masalah.

Berdasarkan hasil tes yang diperoleh terlihat bahwa subjek pertama-tama menyamakan koefisien pada informasi awal dengan mengacu pada soal/masalah yang diberikan. Selanjutnya subjek mulai mengurangkan kedua ruas dengan 3 $\cos ^{2}$ a untuk mendapat bentuk yang sama seperti masalah awal sehingga memudahkan dalam proses substitusi untuk mendapatkan jawaban yang benar. Hal ini dapat ditunjukkan pada penggalan jawaban subjek berikut.

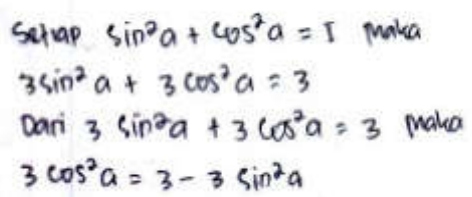

Peneliti selanjutnya mendalami hasil pekerjaan subjek dengan melakukan wawancara mendalam, dimana subjek mengemukakan bahwa " karena 3 ini di dapat dari $3 \sin ^{2} a+3 \cos ^{2} a=3$, jadi 3 ini merupakan aturan identitas trigonometri. Misalnya: $3 \sin ^{2} a+3 \cos ^{2} a=3$ jadi 3 tetap 3, 1 tetap 1 dan tidak dapat di ubah karena ini menggunakan aturan identitas trigonometri". Kemudian hal ini lebih lanjut dipertegas oleh subjek bahwa "saya memperoleh 3 ini dari 3 yang di atas, karena $3 \sin ^{2} a+3 \cos ^{2} a=3$ jadi di turunkan ke bawah". 
Selain itu subjek juga menjelaskan bahwa "saya memperoleh (-3) dari 3 yang diatas, karena 3 di pindah ruaskan ke kiri maka jadi (- 3)."

Hal ini menunjukkan bahwa dalam menyelesaikan masalah tersebut, subjek harus mencari alasan yang cocok dengan masalah yang diberikan dengan menggunakan aturan identitas trigonometri. Kemudian langkah selanjutnya, subjek berusaha tetap relevan dengan ide utama, dan langkah terakhir yaitu bersikap secara sistematis dan teratur dengan bagian-bagian dari keseluruhan masalah. Berdasarkan alasan-alasan tersebut menunjukkan bahwa indikator ketiga dari berpikir kritis terpenuhi.

\section{d. Mampu mendeteksi bias berbeda pada sudut pandang berbeda}

Maksud dari indikator ini yaitu dalam menyelesaikan soal, subjek perlu mencari alternatif, subjek perlu mengambil posisi ketika ada bukti yang cukup untuk melakukan sesuatu; serta mencari penjelasan sebanyak mungkin apabila memungkinkan.

Berdasarkan hasil tes yang diperoleh subjek dalam menyelesaikan masalah yang trigonometri tampak bahwa subjek langsung mensubstitusikan bentuk persamaan $3 \cos ^{2}$ a pada masalah awal dengan tujuan untuk melihat kesamaan dari kedua ruas. Setelah subjek mensubstitusikan dan melakukan pengoperasian dengan variabel dengan derajat yang sama sehingga diperoleh ruas kiri sama dengan ruas kanan. Hal ini dapat ditunjukkan pada penggalan hasil pekerjaan subjek sebagai berikut.

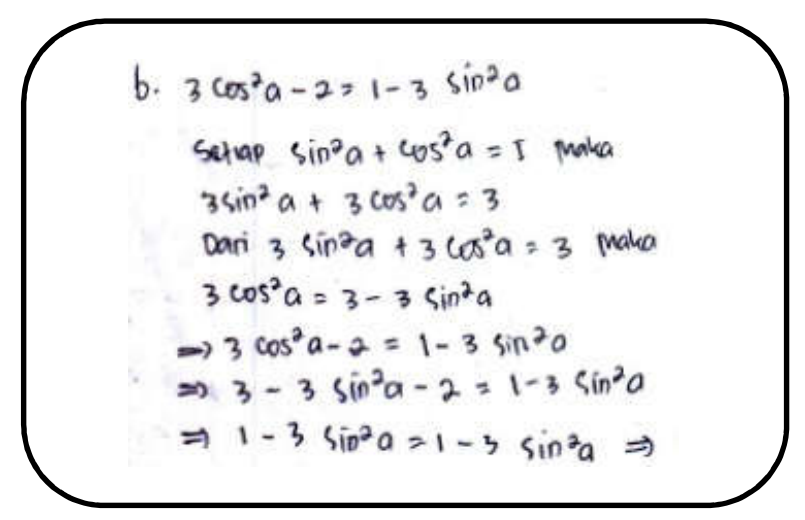

Selanjutnya untuk mendalami hasil kerja subjek, peneliti kemudian melakukan wawancara terhadap subjek tersebut dimana subjek mengemukakan bahwa "saya peroleh dari $3-2=1$. Jadi -3 di turunkan ke bawah. Dan hasil akhirnya menjadi $1-3 \sin ^{2} a=1-3 \sin ^{2} a$. Jadi terbukti ruas kiri dan ruas kanan sama yaitu $1-3 \sin ^{2} a$." Sejalan dengan pendapat Yoenanto (2002) bahwa 
siswa laki-laki lebih tertarik ketika dihadapkan dengan masalah matematika. Selain itu, Krutetskii (1976) menjelaskan bahwa laki-laki dalam belajar matematika lebih unggul dalam penalaran. Sehingga dalam proses penyelesaian, subjek tidak perlu mengurutkan suku-suku yang sama ketika proses pengoperasian. Selain itu, dalam proses penyelesaian, subjek hanya menggunakan satu cara tanpa mendeteksi bias berbeda pada sudut pandang berbeda. Walaupun demikian subjek telah memenuhi indikator mendeteksi bias berbeda pada sudut pandang berbeda.

e. Mampu menentukan akibat dari suatu pernyataan yang di ambil sebagai suatu keputusan.

Pada tahap terakhir dari kemampuan berpikir kritis, maksud dari indikator tersebut yaitu memperhatikan situasi dan kondisi secara keseluruhan dan bersikap dan berpikir terbuka. Ini menunjukkan bahwa subjek perlu tegas dalam mengambil keputusan akhir dengan memperhatikan situasi dan kondisi.

Berdasarkan hasil pekerjaan subjek, terlihat bahwa subjek diakhir proses penyelesaian langsung mengambil kesimpulan terhadap jawaban yang diperoleh. Hal ini menunjukkan bahwa subjek telah yakin dengan jawabannya dan berasumsikan benar. Adapun penggalan hasil pekerjaan subjek dapat ditunjukan sebagai berikut.

$$
\left.\Rightarrow 1-3 \operatorname{Sin}^{2} a=1-3 \sin ^{2} a \Rightarrow \text { (Terbukt }\right)
$$

Dari hasil pekerjaan subjek, peneliti selanjutnya melakukan wawancara mendalam untuk mengkonfirmasi kesimpulan yang dibuat subjek. Berdasarkan hasil wawancara, subjek mengungkapkan bahwa "jawaban saya benar dan sudah terbukti". Peneliti selanjutnya menanyakan terkait dengan proses pembuktian yang digunakan subjek sehingga yakin dengan jawaban yang diperoleh, namun subjek mengungkapkan bahwa " dalam proses pembuktian saya hanya melihat ulang hasil penyelesaian saya dan saya rasa tidak ada kekeliruan yang terjadi karena saya tidak temukan". Sejalan dengan hasil penelitian oleh Sukayasa (2014) bahwa dalam penyelesaian masalah, siswa laki-laki cenderung mampu mendeskripsikan kesimpulan-kesimpulan dan membuat argumen yang logis.

Ini menunjukkan bahwa subjek dalam melakukan pembuktian terhadap jawaban yang diperoleh dengan cara refleksi, selanjutnya subjek menarik 
kesimpulan. Dengan demikian subjek cenderung memenuhi indikator terakhir dari kemampuan berpikir kritis yaitu mampu menentukan akibat dari suatu pernyataan yang di ambil sebagai suatu keputusan.

\section{Paparan data subjek AT berjenis kelamin perempuan dalam menyelesaikan} masalah identitas trigonometri

\section{a. Mampu merumuskan pokok permasalahan}

Indikator pertama dari berpikir kritis adalah mampu merumuskan pokok permasalahan dari masalah yang diberikan. Artinya bahwa siswa mencari pernyataan yang jelas dari setiap pertanyaan yang ada. Subjek dalam mengerjakan soal yang diberikan berupa think a loud tampak bahwa subjek langsung mengerjakan soal tersebut tanpa berpikir lama. Dalam proses menyelesaikannya, subjek menuliskan kembali masalah yang ada pada lembar jawabannya. Hal ini dapat ditunjukan pada penggalan hasil pekerjaan subjek sebagai berikut.

$$
\text { b). } 3 \cos ^{2} a-2=1-3 \cdot \sin ^{2} a
$$

Berdasarkan hasil wawancara, subjek mengungkapkan bahwa "saya paham dengan soal ini. Selanjutnya subjek menjelaskan bahwa " dalam merumuskan pokok permasalahan itu saya hanya menuliskan kembali soalnya dikarenakan soal yang disajikan sudah dalam bentuk kalimat matematika yang berbentuk identitas trigonometri”. Peneliti selanjutnya mendalami bahwa bagaimana cara dibuktikan masalah tersebut, subjek kemudian mengemukakan bahwa "mencari kesamaan dari ruas kiri dan ruas kanan pada masalah tersebut". Dari hasil tes dan wawancara menunjukkan bahwa subjek perempuan tidak terlalu mampu dan tanggap dalam mengenali masalah yang ada dibandingkan laki-laki.

Hal ini menunjukkan bahwa subjek telah memenuhi indikator pertama yaitu mampu merumuskan pokok permasalahan dari masalah yang diberikan.

\section{b. Mampu mengungkapkan fakta yang dibutuhkan dalam menyelesaikan suatu masalah}

Pada indikator ini memiliki makna bahwa dalam proses menyelesaikan subjek dituntut untuk berusaha mengetahui informasi dengan baik; Memakai sumber yang memiliki kredibilitas dan menyebutkannya, serta mengingat kepentingan yang asli dan mendasar. 
Berdasarkan hasil tes yang diperoleh subjek telihat bahwa subjek cenderung dalam proses penyelesaian dengan menuliskan rumus aturan identitas trigonometri yaitu penjumlahan kuadrat sin dan cos adalah 1 . Hal ini ditunjukkan pada penggalan hasil pekerjaan berikut.

$$
\sin ^{2} a+\cos ^{2} a=1
$$

Berdasarkan jawaban subjek menunjukkan bahwa subjek membuktikan masalah yang diberikan dapat dilakukan dengan bantuan aturan identitas trigonometri. Peneliti selanjutnya menggali lebih mendalam terkait penggunaan aturan identitas tersebut. Subjek kemudian mengemukakan bahwa "bentuk tersebut yang di namakan identitas trigonometri adalah $\sin ^{2} a+\cos ^{2} a=1$. Peneliti kemudian mendalami dengan menanyakan terkait rumus tersebut kenapa sama dengan satu, namun subjek secara refleks mengemukakan bahwa " $\sin ^{2} a+\cos ^{2} a$ $=1$ hasilnya memang 1 karena itu merupakan aturan identitas trigonometri tidak bisa di ubah". Sejalan dengan pendapat Myers (2006) bahwasanya tidak ada perbedaan yang nyata kemampuan berpikir kritis antara siswa laki-laki dan perempuan. Hal ini menunjukkan dalam proses pengungkapan fakta dari masalah yang ada untuk proses penyelesaian antara subjek perempuan dan laki-laki cenderung sama.

Dengan demikian berdasarkan fakta tersebut, subjek cenderung telah memahami secara mendalam terkait aturan identitas trigonometri serta informasiinformasi apa yang perlu digunakan dalam menyelesaikan masalah identitas trigonometri. Oleh karena itu, subjek dalam menyelesaikan soal trigonometri cenderung memenuhi indikator kedua dari proses berpikir kritis.

\section{c. Mampu memilih argumen yang logis, relevan dan akurat}

Indikator ini menunjukkan bahwa dalam proses penyelesaian soal, subjek harus mencari alasan yang cocok dengan masalah yang diberikan, berusaha tetap relevan dengan ide utama, serta bersikap secara sistematis dan teratur dengan bagian-bagian dari keseluruhan masalah.

Berdasarkan hasil tes yang diperoleh terlihat bahwa subjek pertama-tama menyamakan koefisien pada informasi awal dengan mengacu pada soal/masalah yang diberikan. Dimana pada bentuk aturan identitas trigonometri, subjek mengalihkan kedua ruas dengan 3. Selanjutnya subjek mulai memindahruaskan 3 
$\sin ^{2}$ a ke ruas kiri untuk mendapat bentuk yang sama seperti masalah awal sehingga memudahkan dalam proses substitusi untuk mendapatkan jawaban yang benar. Hal ini dapat ditunjukkan pada penggalan jawaban subjek berikut.

$$
\begin{aligned}
& 3 \sin ^{2} a+3 \cos ^{2} \cdot a=3 \text { mak } a \\
& 3 \cos ^{2} a=3-3 \sin ^{2} a \\
\Leftrightarrow & 3 \cos ^{2} a-2=1-3 \sin ^{2} a
\end{aligned}
$$

Peneliti selanjutnya melakukan wawancara uuntuk mendalami hasil pekerjaan subjek, dimana subjek mengemukakan bahwa “ untuk memperoleh hasil yang sama saya gunakan aturan identitas trigonometri dengan menyamakan koefisien pada kedua ruas yaitu $3 \cos ^{2} a=3-3 \sin ^{2} a$. Peneliti selanjutnya mendalami dengan menanyakan kenapa demikian? Namun subjek mengemukakan bahwa "untuk mendapatkan hasil akhir dengan mengacu pada masalah awal yang koefisiennya adalah 3. Di sini saya mau terapkan subtitusi”." Kemudian hal ini lebih lanjut dipertegas oleh subjek bahwa "saya peroleh 3 dari atas di pindah ruaskan ke kiri sehingga tandanya berubah menjadi - 3".

Hal ini menunjukkan bahwa dalam menyelesaikan masalah tersebut, subjek harus mencari alasan yang cocok dengan masalah yang diberikan dengan menggunakan aturan identitas trigonometri. Kemudian langkah selanjutnya, subjek berusaha tetap relevan dengan ide utama, dan langkah terakhir yakni bersikap secara sistematis dan teratur dengan bagian-bagian dari keseluruhan masalah. Berdasarkan alasan-alasan tersebut menunjukkan bahwa indikator ketiga dari berpikir kritis terpenuhi.

\section{d. Mampu mendeteksi bias berbeda pada sudut pandang berbeda}

Indikator ini menjelaskan bahwa dalam menyelesaikan soal, subjek perlu mencari alternatif, subjek perlu mengambil posisi ketika ada bukti yang cukup untuk melakukan sesuatu; serta mencari penjelasan sebanyak mungkin apabila memungkinkan.

Berdasarkan hasil tes yang diperoleh subjek dalam menyelesaikan masalah identitas trigonometri tampak bahwa subjek langsung mensubstitusikan bentuk persamaan $3 \cos ^{2}$ a pada masalah awal dengan tujuan untuk melihat kesamaan dari kedua ruas. Setelah subjek mensubstitusikan dan melakukan pengoperasian dengan variabel dengan derajat yang sama sehingga diperoleh ruas kiri sama 
dengan ruas kanan. Namun sebelum subjek melakukan pengoperasian, subjek terlebih dahulu melakukan pengurutan (mengumpulkan) konstanta terlebih dahulu. Hal ini dapat ditunjukkan pada penggalan hasil pekerjaan subjek sebagai berikut.

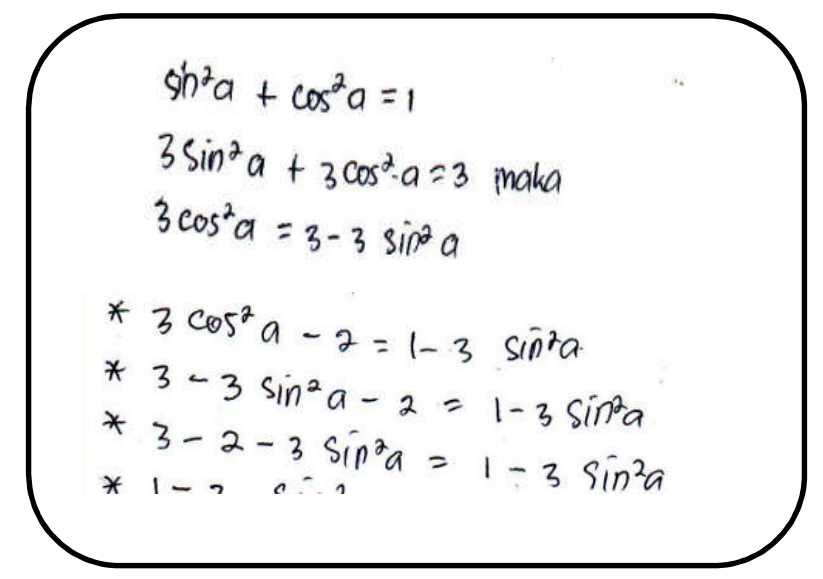

Selanjutnya untuk mendalami hasil kerja subjek, peneliti kemudian melakukan wawancara terhadap subjek tersebut dimana subjek mengemukakan bahwa "saya ikuti dari tahap rumus identitas kemudian mensubstitusikan nilai 3 $\cos ^{2} a$ pada masalah awal (soal) sehingga diperoleh hasil ruas kiri sama dengan ruas kanan. Namun supaya tidak keliru saya pindahkan -2 berdekatan dengan 3 setelah itu baru di operasikan”. Sejalan dengan pendapat Yoenanto (2002) bahwa siswa perempuan dalam menghadapi masalah matematika cenderung lebih mudah cemas. Selain itu, Krutetskii (1976) juga menjelaskan perempuan dalam belajar matematika lebih unggul dalam ketepatan, ketelitian, kecermatan, dan keseksamaan berpikir. Hal ini menyebabkan siswa dalam proses penyelesaian dilakukan secara sistematis dan terurut. Selain itu, dalam proses penyelesaian, subjek hanya menggunakan satu cara tanpa mendeteksi bias berbeda pada sudut pandang berbeda. Ketika peneliti bertanya terkait cara yang lain, namun subjek mengemukakan bahwa " saya biasanya kerjanya begini dan paling mudah itu kerja begini saja dengan menyamakan dikiri dengan di kanan". Walaupun demikian subjek telah memenuhi indikator mendeteksi bias berbeda pada sudut pandang berbeda. 


\section{e. Mampu menentukan akibat dari suatu pernyataan yang di ambil sebagai suatu keputusan.}

Pada tahap terakhir dari kemampuan berpikir kritis yaitu menentukan akibat dari suatu pernyataan yang diambil sebagai suatu keputusan. Maksud dari indikator tersebut yaitu siswa perlu memperhatikan situasi dan kondisi secara keseluruhan dan bersikap dan berpikir terbuka. Ini menunjukkan bahwa subjek perlu tegas dalam mengambil keputusan akhir dengan memperhatikan situasi dan kondisi.

Berdasarkan hasil pekerjaan subjek, terlihat bahwa subjek diakhir proses penyelesaian langsung membuat kesimpulan terhadap jawaban yang diperoleh. Hal ini menunjukkan bahwa subjek telah yakin dengan jawabannya dan berasumsikan benar. Adapun penggalan hasil pekerjaan subjek dapat ditunjukan sebagai berikut.

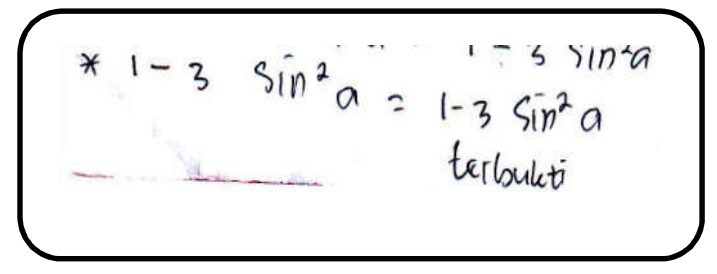

Dari hasil pekerjaan subjek, peneliti selanjutnya melakukan wawancara mendalam untuk mengkonfirmasi kesimpulan yang dibuat subjek. Berdasarkan hasil wawancara, subjek mengungkapkan bahwa "saya sudah yakin dengan jawaban saya karena saya sudah kerja secara terurut". Peneliti selanjutnya menanyakan terkait dengan proses pembuktian yang digunakan subjek sehingga yakin dengan jawaban yang diperoleh, Namun subjek mengungkapkan bahwa “ saya tidak melakukan pembuktian untuk jawaban yang saya peroleh tapi saya hanya mengecek ulang cara penyelesaian saya tahap demi tahap dan tidak ada kekeliruan yang saya temukan sehingga saya yakin dengan jawaban saya tersebut benar". Sejalan dengan hasil penelitian oleh Sukayasa (2014) bahwa dalam penyelesaian masalah, siswa perempuan cenderung dalam mendeskripsikan kesimpulan-kesimpulan dan membuat argumen sebagian bersifat logis.

Ini menunjukkan bahwa subjek dalam melakukan pembuktian terhadap jawaban yang diperoleh dengan cara refleksi. Dalam proses refleksi, tampak bahwa subjek cenderung teliti dan sistematis dalam menyelesaikan soal yang 
diberikan. Hal tersebut ditunjukan dengan cara penyelesaian secara bertahap. Selanjutnya subjek setelah yakin dengan jawaban yang diperoleh subjek kemudian menarik kesimpulan. Hal ini menunjukan bahwa subjek cenderung memenuhi indikator terakhir dari kemampuan berpikir kritis yaitu Mampu menentukan akibat dari suatu pernyataan yang di ambil sebagai suatu keputusan.

\section{KESIMPULAN DAN SARAN}

Berdasarkan hasil penelitian dan pembahasan yang telah dipaparkan sehingga dapat disimpulkan bahwa kemampuan berpikir kritis siswa dalam menyelesaikan soal identitas trigonometri diantaranya siswa yang berjenis kelamin laki-laki (SM) dan siswa yang berjenis kelamin perempuan (FM) cenderung memenuhi 5 indikator berpikir kritis yaitu (1) mampu merumuskan pokok permasalahan; (2) mampu mengungkapkan fakta yang dibutuhkan dalam menyelesaikan suatu masalah; (3) mampu memilih argumen yang logis, relevan dan akurat; (4) mampu mendeteksi bias berbeda pada sudut pandang berbeda dan (5) Mampu menentukan akibat dari suatu pernyataan yang di ambil sebagai suatu keputusan. Dalam proses penyelesaian, siswa AT yang mewakili perempuan cenderung teliti dan sistematis dibandingkan siswa SM yang mewakili laki-laki.

Dalam pembelajaran matematika dibutuhkan kemampuan berpikir kritis yang tinggi. Agar siswa dapat memanfaatkan kemampuan berpikir kritisnya dalam menyelesaikan masalah matematika, maka disarankan kepada para pendidik untuk memperhatikan perbedaan gender dalam pembelajaran, khususnya dalam melatih berpikir kritis dan latihan soal yang diberikan lebih menantang sehingga mereka dapat mengembangkan berpikir kritis melalui pemecahan masalah. Selain itu, disarankan untuk penelitian selanjutnya agar dapat melajutkan penelitian ini dengan menggunakan latar belakang siswa yang lainnya yaitu berupa kemampuan kognitif.

\section{DAFTAR RUJUKAN}

Ekawati, Aminah dan Shinta Wulandari. (2011). Perbedaan Jenis Kelamin Terhadap Kemampuan Siswa dalam Mata Pelajaran Matematika (Studi Kasus Sekolah Dasar). Jurnal Universitas Borneo Tarakan.

Ennis, R.H. (2000). A super-steamlined conception of critical thinking. Tersedia: http://www.ed.uine.edu/EPS/PES-yearbook/92.does/ennis.htm 
Facione,PA. (2010). Critical Thinking: What is and Why It Count. Insight Assesment. $1-24$

Fowler, G. (2004). Critical thinking across teh curriculum projek. Tersedia: http://ww.kemetro.cc.mo/us/longview/etac/definition.htm

Hassoubah, Izhab Zaleha. (2004) Developing Creatif and Critical Thingking Skill (cara berpikir kritis dan kreatif). Nuansa. Bandung

Krutetskii, V.A. (1976). The Psychology of Mathematics Abilities in School Children. Chicago: The University of Chicago Press.

Myers, B.E., Dyer, J.E. (2006). The Influence Of Student Learning Style On Critical Thinking Skill. In Journal of Agricultural Education, 47, (1).

Rita L. Atkinson, et.all., Pengantar Psikologi, Batam: Interaksara. 172

Sugiyono. (2006). “Metode Penelitian Kuantitatif Kualitatif dan R\&D”. Bandung: Alfabeta

Sukayasa. (2014). Karakteristik Penalaran Siswa SMP Dalam Memecahkan Masalah Geometri Ditinjau Dari Perbedaan Gender. Program studi pendidikan matematika universitas Tadulako: Jurnal Pendidikan Matematika, Volume 03 Nomor 01.

Suriadi. (2006). Pembelajaran Dengan Pendekatan Discovery Yang Menekankan Aspek Analogi Untuk Meningkatkan Pemahaman Matematika Dan Kemampuan Berpikir Kritis Siswa SMA. Tesis pada PPs UPL, Tidak dipublikasikan. 